\title{
The Three Roles of Neaira
}

\section{T. V. Kudryavtseva}

For citation: Kudryavtseva T. V. The Three Roles of Neaira. Vestnik of Saint Petersburg University. History, 2021, vol.66, issue 1, pp. 163-178. https://doi.org/10.21638/11701/spbu02.2021.110

The article examines one of the most striking speeches of the Demosthenes corps, which was often quoted by ancient authors: LIX "Against Neaira," conventionally believed to be authored by Apollodorus. Although this speech, as well as the trial where it was presented, has repeatedly become the subject of historiographic commentary and discussion, not a single specialized work has been devoted to it in Russian. The trial against Neaira and her partner Stephanos is of interest not only because it is the only surviving case on charges of illegal acquisition of Athenian citizenship, and the plaintiff's speech allows us to reconstruct a number of important aspects of legal proceedings in Athens (litigants' behavior, arguments, witnesses, evidence, etc.). The prosecutor also reveals certain unappealing aspects of the daily life of Greek society in terms of attitudes to women, prostitution and pedophilia. The speaker divides women into three categories: wife, concubine ( $\pi \alpha \lambda \lambda \alpha \kappa \eta$ ) and hetaera. Neaira successfully handled the roles of hetaera and concubine. It is unknown whether Apollodorus had managed to impose on her the role of a legal wife - the one that would put Neaira at risk of being sold into slavery. Despite the weakness of the prosecution's arguments and evidence, Apollodorus, who skillfully used the concept of polis rules, family identity and religious values, as well as dikastes' prejudices, could have become the winner. However, presenting sufficiently convincing counter-arguments and testimonies may not have been difficult for Stephanos, although, perhaps, an appeal to the mercy and pity of the judges would have been a more efficient way to achieve his goal.

Keywords: Ancient Greece, Athens, trial, Apollodorus, Neaira, Stephanos, marriage, concubine, hetaera.

\section{Три роли Неэры}

\section{T. В. Кудрявиева}

Для цитирования: Kudryavtseva T. V. The Three Roles of Neaira // Вестник Санкт-Петербургского университета. История. 2021. Т.66. Вып. 1. С. 163-178.

https://doi.org/10.21638/11701/spbu02.2021.110

Tatyana V.Kudryavtseva - Dr. Sci. (History), Professor, Herzen State Pedagogical University, 48, nab. r. Moiki, St. Petersburg, 191186, Russian Federation; tvkudryavtseva@herzen.spb.ru

Татьяна Владимировна Кудрявиева - д-р ист. наук, проф., Российский государственный педагогический университет им. А.И.Герцена, Российская Федерация, 191186, Санкт-Петербург, наб. p. Мойки, 48; tvkudryavtseva@herzen.spb.ru

The paper was created within the project financed by RFFI: No. 19-09-00183 (Judicial process in antiquity: legal, political, social and personal aspects).

Статья подготовлена при финансовой поддержке РФФИ: проект № 19-09-00183 («Судебный процесс в античности: юридические, политические, социальные и личностные аспекты»).

(C) St. Petersburg State University, 2021 
В статье исследуется одна из самых ярких и популярных речей Демосфенова корпуса, которую часто цитировали античные авторы и лексикографы - речь LIX «Против Неэры». Ее автором, по общепринятому мнению, является Аполлодор. Хотя данная речь, а также судебный процесс, на котором она была представлена, неоднократно становились предметом комментирования и обсуждения в историографии, на русском языке нет ни одной специальной работы, ей посвященной. Процесс против Неэры и ее сожителя Стефана представляет интерес не только потому, что это единственное дошедшее до нас дело по обвинению в незаконном присвоении афинского гражданства, а речь истца позволяет реконструировать ряд важных моментов афинского судопроизводства (подача иска, поведение тяжущихся, их аргументация, свидетели и свидетельства и т. п.). Обвинитель поведал о некоторых неприглядных сторонах повседневной жизни греческого общества с точки зрения отношения к женщине, женской проституции и педофилии. Оратор делит женщин на три категории, у каждой из которых свое пред-

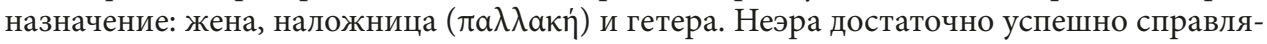
лась с ролями гетеры и конкубины. Удалось ли Аполлодору навязать бывшей куртизанке третью роль из возможных для женщины в Афинах - роль законной жены, что грозило бы Неэре продажей в рабство, - неизвестно. Анализируется аргументация обвинителя, высказывается ряд соображений о возможном исходе процесса. Несмотря на слабость доводов обвинения и манипуляцию со свидетельствами, Аполлодор, который умело использует представления о полисных устоях, семейной идентичности и религиозных ценностях, а также предрассудки и сексистские предубеждения дикастов, мог оказаться победителем. Однако Стефану не составило бы труда представить достаточно убедительные контрдоводы и свидетельства, хотя, возможно, более эффективным путем к достижению цели стало бы взывание к милосердию и жалости судей.

Ключевые слова: Древняя Греция, Афины, судебный процесс, Аполлодор, Неэра, Стефан, брак, конкубина, гетера.

It has been established that one of the most outstanding and popular speeches by Demosthenes, which was often quoted by ancient authors and lexicographers, speech LIX "Against Neaira", was mistakenly attributed to him ${ }^{1}$. It is known that the corpus of Demosthenes' texts comprising 61 speeches was compiled by Callimachus in the middle of the III century BC, and even Dionysius of Halicarnassus criticized him for ascribing wrong speeches to orators (Dyon. Hal. Dem., 13). A large number of ancient writers raised doubts concerning the authorship of Demosthenes of the speech LIX (Dyon. Hal. Dem.,

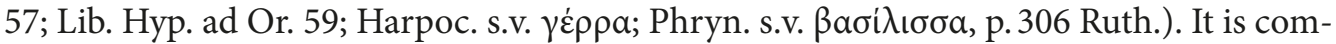
monly held that the speech against Neaira was written by Apollodorus ${ }^{2}$. He might have been the author of some other speeches from Demosthenic corpus ${ }^{3}$.

${ }^{1}$ Prominent commentators on Demosthenes wrote about it even in the XIX c.: Schäfer A.D. Demosthenes und seine Zeit: in 3 Bdn. Bd. III. Leipzig, 1858. S. 179-184; Blass F. Die attische Beredsamkeit: in 4 Bdn. Bd. III. 1. Abschnitt: Demosthenes. Leipzig, 1893. S. 535; Sandys J. E. Introduction to Or. XLV, XLVI // Select Private Orations of Demosthenes: in 2 parts. Pt. 2. Cambridge, 1886. P.XLV.

2 Patteson A. J. Commentary on [Demosthenes] LIX: Against Neaera. Diss. in Classical Studies. Pennsylvania, 1978. P.4; Trevett J. Apollodoros the Son of Pasion. Oxford, 1992. P. 73; Patterson C. The Case against Neaira and the Public Ideology of the Athenian Family // Athenian Identity and Civic Ideology. Baltimore; London, 1994. P. 200; Carey C. Introduction // Greek Orators: in 7 vols. Vol. VI: Apollodoros Against Neaira [Demosthenes] 59. Warminster, 1992. P. 17; Kapparis K. A. Apollodoros "Against Neaira": [D. 59]. Berlin; New York, 1999. P. 50; Hamel D. Trying Neaira: the True Story of a Courtesan's Scandalous Life in Ancient Greece. New Haven; London, 2003. P. XII.

3 The following speeches were most often ascribed to Apollodorus - № 46, 49, 50, 52, 53, 59, sometimes - № 45, 47 и 51. The analysis of different viewpoints and arguments: Trevett J. Apollodoros the Son of Pasion. P. 50-76; Kapparis K. A. Apollodoros "Against Neaira". P. 48-50. 
Apollodorus (born circa 394) was the eldest son of the famous Athenian banker Pa$\operatorname{sion}^{4}$, a former slave who was granted citizenship for his services to Athenians ([Dem.], LIX, 2). Pasion, a fortunate and sharp trader, had accumulated a considerable wealth - by the time of his death in 370/369 it amounted to 70 talents (Dem., XXVI, 5). Similarly to his father, Apollodorus had performed trierarchies and other liturgies on repeated occasions. By the time of Neaira's trial, he had proved himself to be an active litigant and orator in courts.

The charges against Neaira - part of a long-standing confrontation between Apollodorus and Stephanos, who belonged to different political groups. Their mutual enmity was reflected in a series of lawsuits and eventually turned into vendetta. The political context of the confrontation was concerned with the attitude to Macedon and the choice Athens had to make with regards to the relationships with the kingdom of Philip II, which had suddenly emerged onto the Greek political arena. Stephanos (born circa 410-400) at the end of the 60s was connected with an Athenian politician Callistratus ([Dem.], LIX, 43), and later joined Eubulus' party. The latter, one of the leaders of Athens, since the middle of the 50s had tried to avoid costly (in every sense of the word) conflicts with Macedon ${ }^{5}$, and his primary achievement was reorganization of Theorica (festival fund). The Theoric fund not only enabled the poorest citizens to attend theatres but was also used to finance a range of public projects: constructing docks and arsenals, building roads etc (Aeschin, III, 25; Din. I, 96). It was forbidden to withdraw money from the fund. Apollodorus acting in his capacity as a bouleutes in $349 / 48$, prompted by Demosthenes as it is generally believed, proposed that the Athenians decide themselves whether the money should be used for military purposes or for public spectacles ([Dem.], LIX, 4-5). Stephanos complained of this decree being illegal; Apollodorus lost a lawsuit and was obligated to pay the fine at one talent ([Dem.], LIX, 8). Sometime later Stephanos attempted, albeit in vain, to accuse Apollodorus of murder: as if he had beaten a woman who died of injuries ([Dem.], LIX, $9-10)^{6}$. It was alleged that the charge against Neaira - another stage in the conflict concerning festival money, and that Apollodorus again acted for the benefit of Demosthenes, who tried to channel Theoric fund into military needs ${ }^{7}$. However, this time the object of the attack was not his opponent but Neaira, Stephanos' mistress, although Stephanos would have to defend a claim. Women were not allowed to appear in courts as litigants, they were represented by their custodians, kúpıoc. If a woman was unmarried, it was her father, and in the case of his death - her brother, grandfather, uncle etc. A married wom-

${ }^{4}$ On Pasion and his family, see: Davies J. K. Athenian Propertied Families (600-300 B. C.). Oxford, 1971. P. 427-442; Trevett J. Apollodoros the Son of Pasion. P.1-17. From sources, in particular - Dem., XXVI; Isocr., XXVII.

${ }^{5}$ Carey calls Eubulus a moderate pacifist, and his policy regarding Macedon - cautious pragmatism: Carey C. Introduction. P. 6.

${ }^{6}$ Kapparis dates this process to 346 (Apollodoros "Against Neaira". P. 29). Patteson hypothesized that the victim was a slave on the ground that the case was heard in Palladium (Commentary on [Demosthenes] LIX. P. 34-35). However, the Court at the temple of Pallas besides cases of murder or mutilation of metics or slaves, also dealt with cases of manslaughter (Aristot. Ath. pol., 57, 3).

7 Macurdy G. H. Apollodorus and the Speech against Neaera (Pseudo-Dem. LIX) // American Journal of Philology. Vol. 63. 1942. P. 259; Patteson A. J. Commentary on [Demosthenes] LIX. P. 5, 39; Trevett J. Apollodoros the Son of Pasion. P. 146-150. - Carey suggests that the political aspect of the process is in a wider context concerned Demosthenes's attack at Aeschines and other supporters of peace with Macedon (Introduction. P. 80). 
an was represented by her husband. Although Neaira was not Stephanus's wife but his concubine ( $\pi \alpha \lambda \lambda \alpha \kappa \eta \dot{)})$, he could act as her $\kappa \dot{\rho} \rho \varsigma^{8}$ in court.

Theomnestus, Apollodorus's brother-in-law and son-in-law ${ }^{9}$, officially brought charges against Neaira, however, having introduced the case, he called Apollodorus to assist him in trial on account of his wider experience and better acquaintance with laws ([Dem.], LIX, 15). Afterwards the speech was continued by Apollodorus as a plaintiff's

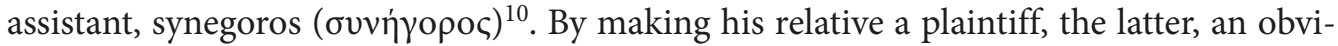
ous initiator of the suit, emphasized that accusations of Neaira and Stephanos of insulting family values were brought by a family, oikos ${ }^{11}$. It cannot be ruled out, nevertheless, that Apollodorus, prior to this, having lost a suit based on a written complaint ( $\gamma \rho \alpha \varphi \eta ́)$ received fewer than 1/5 votes of dikastes: if it was the case, he was deprived of the right to file a lawsuit ${ }^{12}$. It was also assumed that Apollodorus took into consideration a biased attitude of the Athenians to those who often appeared in court, and thus decided to turn the spotlight on his young relative ${ }^{13}$. Even if he was forced to yield initiative, his strategy and charges determined by it created a wider context for litigants: from the framework of a political confrontation and private vengeance it turned into the case regarding the fundamental principles of Athenian society and civil identity.

Theomnestus's lawsuit is the only case of usurping Athenian citizenship that has survived to the present day ( $\gamma \rho \alpha \varphi \eta \grave{~} \xi \varepsilon v i \alpha \varsigma)$. The plaintiff accuses Neaira, a former hetaera and an alien, of cohabiting with Stephanus as his wife. He refers to the law of Athens which states that if an alien shall live as husband with an Athenian woman and is convicted, he shall be sold, himself and his property; the same principle shall hold also if an alien woman shall live as wife with an Athenian, and the Athenian who lives as husband with the alien woman so convicted shall be fined one thousand drachmae ([Dem.], LIX, 16) ${ }^{14}$.

Neaira's trial took place between 343 and 340, closer to the low end of the range, i.e. $340^{15}$, when the accused was well over fifties. The case is of interest for a number of reasons. A woman in the Athenian polis rarely comes to the fore ${ }^{16}$, however, speech LIX from Demothenes' corpus enables to get acquainted with a dramatic fate of Neaira in details almost since her birth and until maturity.

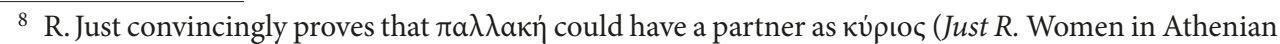
Law and Life. London; New York, 1991. P. 52-53).

${ }^{9}$ His sister married Apollodorus, and Theomnestus married their daughter, his own niece.

${ }^{10}$ At the end of the speech, Apollodorus, being carried away, starts using first-person pronoun, having

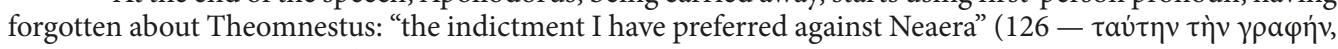

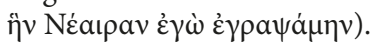

${ }_{11}$ Patterson C. The Case against Neaira... P. 203-204.

12 Kapparis K. A. Apollodoros "Against Neaira". P. 196. - On different types of lawsuits and punish-

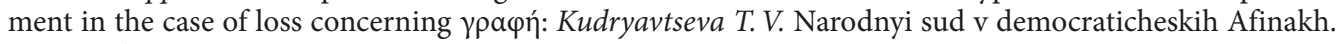
St. Petersburg, 2008. S. 180-188.

13 Carey C. Introduction. P. 5.

${ }^{14}$ Most scholars consider the text of the law to be authentic: Kapparis K. A. Apollodoros "Against Neaira". P. 198-199 (with references).

${ }_{15}$ Blass F. Die attische Beredsamkeit: in 4 Bdn. Bd.III. 1. S. 536; Macurdy G. H. Apollodorus and the Speech against Neaera. P. 258; Patteson A. J. Commentary on [Demosthenes] LIX. P. 4, 7; Carey C. Introduction. P. 3; Kapparis K. A. Apollodoros “Against Neaira”. P. 28; Hamel D. Trying Neaira. P. 130.

${ }^{16}$ For details see: Kudryavtseva T. V. Zhenshina i polis: afinskaia gorozhanka v narodnom sude // Gorod v Antichnosti i Srednevekov'e: obshcheevropeiskii kontekst. Doklady mezhdunarodnoi conferentsii: v 2 ch. Ch. 2. Iaroslavl', 2010. S. 14-17. 
In addition, the accuser reveals some unpleasant aspects of everyday life of the Greek society with regard to its attitude to women, female prostitution, pedophilia etc. The speech by Apollodorus is one of the most blatant evidence of male chauvinism in antiquity. The orator divides women into three categories, each serving its own purpose: wives, concubines ( $\pi \alpha \lambda \lambda \alpha \kappa \eta \dot{)}$ and hetaeras (mistresses): "Mistresses we keep for the sake of pleasure, concubines for the daily care of our persons, but wives to bear us legitimate children and to be faithful guardians of our households"([Dem.], LIX, 122) ${ }^{17}$. Hetaera

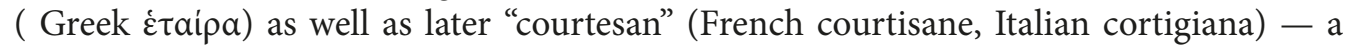
known euphemism for $\pi$ ó $\rho v \eta$ (prostitute) denoting a highly skilled woman of easy virtue. Here the word is used in a wide sense meaning all types of prostitution ${ }^{18}$.

The text sheds light on how sex trade was organized in the Greek society, which was in high demand and yielded a considerable profit to brothel-keepers and souteneurs. It informs that the Neaira was purchased as a child ${ }^{19}$ by some Nikarete, the Corinthian, a freedwoman and presumably a former courtesan herself. She was in pursuit of "budding beauty of young girls and knew well how to bring them up and train them artfully in her

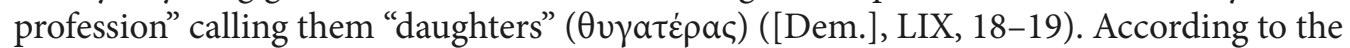
orator, Neaira started the trade of a prostitution "young as she was; for she was not yet old

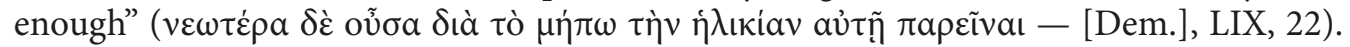
The word 'H入ıkia in relation to a girl meant that she had not reached marriageable age, which was 14-15 in Athens (Dem., XXIX, 43; Xen. Oec. VII, 5; Arist. Ath. pol., 56, 7), i.e. Neaira was $12-13$ years old at the time ${ }^{20}$.

It is known from sources that prostitution in Greece had been legalized for a long time: Athenaeus (alluding to the comedy by Philemon) stated that first brothels were established in Athens by Solon who made use of their profit to construct a sanctuary in honour of

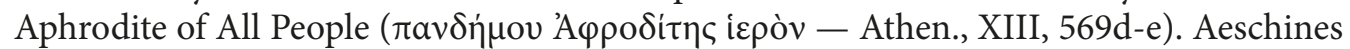
dispassionately listed brothel-keepers and prostitutes ( such occupations as doctors, blacksmiths, carpenters etc. (Aeschin., I, 124). The income of both brothel-keepers and those involved in prostitution independently was subject to a

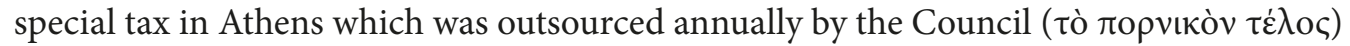
(Aeschin., I, 119). Venal love not restricted either by moral codes or laws was available to anyone, even to slaves (Aristh. Vesp., 500-502). The cost varied from obol to one-two drachmae (or even more) depending on the services and skills of a prostitute. Undoubtedly, exclusive hetaeras, escorting their clients to symposions and other banquets, provided not only sex but also intellectual and aesthetic pleasures and charged much more - from 10 to 100 drachmae a night ${ }^{21}$. Our heroine obviously made a brilliant career of a courtesan as did Phryne or Metaneira (one of Neaira friend, a mistress of a famous orator Lysias).

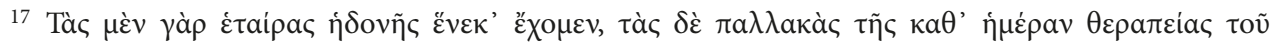

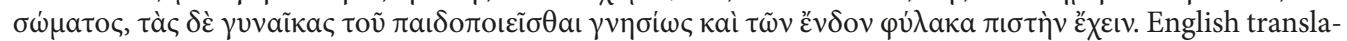
tion here and further from: Demosthenes with an English translation by Norman W. DeWitt, and Norman J. DeWitt. Cambridge; London, 1949.

18 Kapparis K.A. Apollodoros "Against Neaira". P. 5.

19 Neaira's lifespan is usually dated between 400 and 395; she might have been purchased by Nikarete either at the end of the 90 s or at the very beginning of the 80 s of the IV c.: Carey C. Introduction. P.3; Hamel D. Trying Neaira. P.XVII, 4.

${ }^{20}$ Kapparis K. A. Apollodoros "Against Neaira". P. 214-215.

21 Davidson J. Courtesans and Fishcakes: The Consuming Passions of Classical Athens. London, 1997. P. 196. - Compare with the wages of a skilled labourer at the end of the $\mathrm{V} c$. who received from one to one and half drachmae a day. 
Such fortunate women were under the protection of their wealthy and generous clients, and their long-lasting relationships could be transformed into love affairs. However, very few managed to reach this level, and only those who had succeeding in obtaining freedom at least. As for the "daughters" of Nikarete (Appolodorus lists six, besides Neaira, - Anteia, Stratola, Aristocleia, Metaneira, Phila, Isthmias), they had to give all the money and even gifts to their brothel-keeper ([Dem.], LIX, 18, 21). Nikarete was experienced in her sphere: all her "wards" were set free eventually and settled down well (([Dem.], LIX, 20).

Among the events mentioned by the accuser during the time when Neaira stayed with Nikarete, the story about their first visit to Athens is noteworthy: Lysias arranged it for Metaneiara who was accompanied by Neaira and Nikarete. The orator meant this trip to be a gift for his lover: in addition to "the other expenditures which he lavished upon her", he also wanted to initiate her in mysteries (and to compensate all the expenses pertaining to it) ${ }^{22}$. According to Apollodorus, Lysias "did not bring them to his own home, out of regard for his wife", and "lodged them" with his bachelor friend Philostratus ([Dem.], LIX, 22) ${ }^{23}$. Next time Neiara happened to be in Athens with Simus the Thessalian who arrived there for the Great Panathenaea. The girl was also accompanied by Nikarete. Given that this festival was celebrated once in four years, the most convincing date for the visit can be summer of $378^{24}$. The whole company were enjoying their time: the accuser empathizes that Neaira "drank and dined with them in the presence of many men, as any

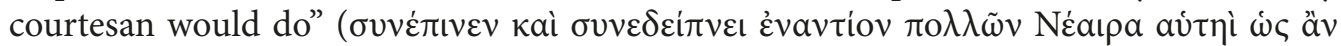

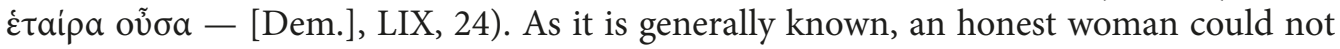
partake in symposions, and the mere fact of her presence at a banquet equated her with a woman of easy virtue (Is., III, 14) ${ }^{25}$. Judging by the above-mentioned examples, Nikarete's house was highly regarded by wealthy and educated clients, from other poleis as well, so it enjoyed all-Hellenic popularity; Neaira must have been one of Nikarete's "star". When Neaira's lovers ("Timanoridas the Corinthian and Eucrates the Leucadian") purchased her from Nikarete in order to have the girl to their service exclusively, her owner received a considerable sum of thirty minae, i.e. 3000 drachmae (Is., III, 29). It can be compared to the cost of slaves-craftsmen from the manufactory left to Demosthenes by his father, where an artisan was worth from three to five minae (Dem., XXVII, 9), and an "ordinary" slave -2 minae (Dem., XLI, 8). Hetaeras were much more expensive, but Neaira was bought at the highest price.

After a while, when Neaira's lovers decided to marry, they (or, perhaps, not both simultaneously but one of them) suggested she should buy her freedom ${ }^{26}$ with a discount at 20 minae. The orator stresses their good intentions: "they did not want to see her, who had been their own mistress, plying her trade in Corinth ${ }^{27}$ or living under the control of

${ }^{22}$ This visit is usually dated to circa. 380 (Patteson A. J. Commentary on [Demosthenes] LIX. P. 5253). Kapparis supposes that it was during the Lesser Eleusinian Mysteries (the month of Anthesteria), dating the visit to February of the end of 80s (Apollodoros "Against Neaira". P. 212).

${ }^{23}$ Apollodorus reads his testimony in court ([Dem.], LIX, 23).

${ }^{24}$ Kapparis K. A. Apollodoros "Against Neaira". P. 217; Hamel D. Trying Neaira. P. 23.

25 This is a fundamental principle of Athenian public life (Just $R$. Women in Athenian Law and Life. P. 143).

${ }^{26}$ Kapparis supposes that Timanoridas and Eucrates bought Neaira in 376, owned her for a year approximately and suggested she should buy herself out at the end of 375/4 or the beginning of 374/3 (Apollodoros "Against Neaira". P. 228).

27 Most probably not to ruin her lovers' reputations seeking to settle down in Corinth and breaking away with their rough past. 


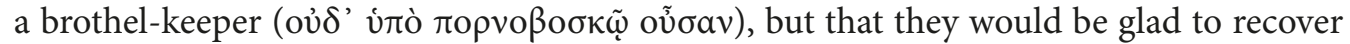
from her less than they had paid down, and to see her reaping some advantage for herself

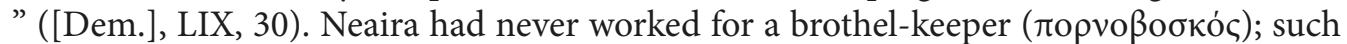
places catered to undiscerning clientele, including slaves ${ }^{28}$. There was almost no chance of leaving such a place, and the future prospects involved physical abuse, diseases, poverty and untimely death ${ }^{29}$; whereas Nikarete offered relatively comfortable conditions, sophisticated and generous clients with long-standing relationships. However, noble intentions of Timanoridas and Eucrates were dubious: Neaira was not young by the standards of sex market - she was over 20, and they were unlikely to receive the money paid for her previously. Neaira called on her former lovers to raise the $\operatorname{sum}^{30}$. Phrynion from Athens ${ }^{31}$ was most responsive, came to Corinth, added the missing sum, and complying with the necessary procedure in the presence of witnesses handed all the money -20 minae - to Timanoridas and Eucrates ([Dem.], LIX, 31-32).

Finally Neaira gained freedom ${ }^{32}$, but not a sense of well-being. Her lover, a represen-

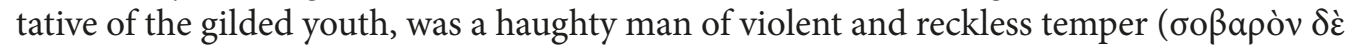
кaì ỏ $\lambda i \gamma \omega \rho o v$ - [Dem.], LIX, 37) in addition to being lewd, and treated Neaira accordingly ([Dem.], LIX, 33). He took her to all his parties. Apollodorus describes one of such symposions given by Chabrias ${ }^{33}$ to celebrate his victory in the chariot race in the Pythean Games: after drunken Phrynion fell asleep, Neaira had to serve all guests, including household slaves of Chabrias ([Dem.], LIX, 34) $)^{34}$.

${ }^{28}$ For more information about life in such places - see fragments from comedies by Eubulus (Eub. PCG, fr. 67, 82), Philemon (Philem. PCG, fr. 3) and Xenarchus (Xen. PCG, fr. 4), and the second mime by Herodas. Also: Kapparis K. A. Apollodoros “Against Neaira". P. 228-229; Davidson J. Courtesans and Fishcakes. P. 83-91.

29 The speech by Antiphon "Against the Stepmother" narrates the story of a slave, a concubine ( $\pi \alpha \lambda \lambda \alpha \kappa \eta$ ) of Philoneous from Athenes. Having learnt that the owner plans to send her to the brothel (probably being tired of her), she was ready to recourse to black magic adding a concoction to the drinks of Philoneous and his friend, the plaintiff's father. For more details, see: Kudryavtseva T. V. Magiia i protsessy po "veneni crimen" v afinskoi i rimskoi sudebnoi praktike // Mnemon. Issledovaniia i publikatsii po istorii antichnogo mira. 2012. Issue 11. S. 274-275.

30 I. e., there was organized a kind of charity club - Épavo, , whose members raised money for Neaira. About the practice of ransom by means of payments from eranos-clubs: Dovatur A. I. Rabstvo v Attike VI-V veka do n. e. Leningrad, 1980. S. 98 (references to scholarship - Ibid).

31 Phrynion of Paeania came from a wealthy family, and was probably Demothenes' cousin: Kirchner J. Prosopographia Attica: in 2 Bnd. Bd. I. Berlin, 1901. S. 254 (3737); Davies J. K. Athenian Propertied Families. P. 143-144.

32 On the practice of ransoming hetaeras and transforming them into mistresses, see: Grace (Kazakevich) E. O konkubinate v Afinakh klassicheskogo perioda // Vestnik drevnei istorii. 1968. No. 1. P.32-38. It is noteworthy that Apollodorus was accused by his opponent in court in the speech "For Phormion" that he, having a wife, ransomed one hetaera and assisted in the marriage of another with a dowry (Dem., XXXVI, 45). This behavior is not very compatible with the image of a strict moralist opposing licentious hetaeras in the name of family values, which Apollodorus projects in his speech "Against Neaira".

33 Chabrias (born circa 420-357), from a deme of Aexone, was a famous politician and military man who defeated the Spartan fleet in the battle of Naxos. He was renowned for his wealth and lavish lifestyle (Nep. Chabr.,3), and lost his life heroically besieging Chios in the War of the Allies. (Davies J. K. Athenian Propertied Families. P. 560-561). His mentioning here is indicative of Neaira's environment.

${ }^{34}$ Eva Keuls supposed that a group of men took advantage of the situation and raped Neaira. The researcher refers to numerous scenes depicted on the vases illustrating sexual intercourse or coercion, making a conclusion that "sexual violence was an integral part of symposium and Athenian society had a high degree of tolerance for it" (Keuls E. C. The Reign of the Phallus: Sexual Politics in Ancient Athens. Berkeley, 1993. P. 182; scenes on vases - Illust. 164-170). 
Eventually ${ }^{35}$, being tired of abuse, she ran off to Megara having taken with her clothing, jewelry and two maids ([Dem.], LIX, 35) ${ }^{36}$. She spent two years there involved in her trade and leading a modest lifestyle. According to the plaintiff, she did not have "enough money to maintain her establishment" ([Dem.], LIX, 36). Megara - as a large trading polis - was a well-known centre of prostitution, however, Neaira was not lucky: another war between Athens and Sparta was in progress (374/3-37), and there were few prospective foreign clients there (who were most profitable). It was in Megara that she acquainted with

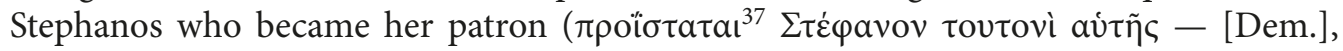
LIX, 37). She came to Athens with him. The accuser states that she brought three children: a daughter Phano and two sons, Proxenus and Ariston. Apollodorus refers to them as Neaira's children - it is his surmise not confirmed by any evidence. When Phrynion learnt about her arrival, he took some young men and forcibly returned her. Stephanos did not give in and took her away from him, as the law allowed, declaring her to be a free

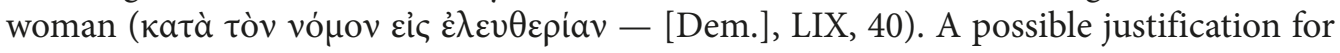
Phrynion's claim to Neaira was the fact that she had not paid back the money for ransoming $^{38}$. As Neaira was an alien (metic), the archon-polemarch assigned Stephanos and two Athenians to be her sureties in court ([Dem.], LIX, 40). They resolved the case in arbitration - Phrynion brought a lawsuit.

According to arbitrators (Apollodorus reads their testimonies), Neaira was declared free; everything she had taken from Phrynion's house was to be returned except "the clothing, the jewels and the maid-servants; for these had been bought for the use of the woman herself" ([Dem.], LIX, 46). However, it did not follow that Stephanos and Neaira had won. A compromise - a common outcome of cases dealt with by arbitrators meant that Phrynion and Stephanos were allowed to share her favours: "each of them shall keep Neaera at his house and have her at his disposal for an equal number of days in the month, unless they shall themselves agree upon some other arrangement" ([Dem.], LIX, 47). Stephanus must have found a solution to the problem to relieve Neaira from the necessity of serving Phrynion, however, the orator does not include these details for an obvious reason. Apollodorus's version of the relationships between Neaira and Phrynion, based on the evidence from witnesses, narrates of the woman's suffering and abuse by her lover and of her struggle for the right to her own life. It can be assumed that dikastes might have felt some sympathy towards Neaira despite prejudice to such women. This was outside the accuser's scope, therefore, he tried to finish his narrative by referring to testimonies of those who dined and partied with Phrynion, Stephanos and Neaira ([Dem.], LIX, 48). Apollodorus did not appeal to Phrynion as a witness, perhaps, because his testimony might have contributed to the sympathy towards the hetaera ${ }^{39}$.

${ }^{35}$ Neaira lived with Phrynion for about 2 years, from 375/4 to 373/2.

36 Apollodorus stresses that it was not only Phrynion's gifts (it was a common practice to present jewelry and expensive clothes to a lover; see Dem., XLVIII, 55), but also other valuable belonging kept in the

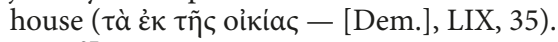

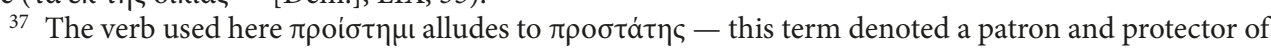
metics and freedmen (Patteson A. J. Commentary on [Demosthenes] LIX. P. 68).

38 Patteson A. J. Commentary on [Demosthenes] LIX. P. 64, 69, 72. According to epigraphy (SGDI II, $2317,9,10$ ), a slave man or woman whose freedom was bought by eranos-club had to return the loan, otherwise he might become a slave again: Dovatur A. I. Rabstvo v Attike VI-V veka do n. e. P. 98, footnote 78.

39 Kapparis hypothesized that by the time of the process Phrynion had beem dead (Apollodoros "Against Neaira". P. 230), Davies doubts it (Athenian Propertied Families. P. 144). 
Afterwards a new stage in Neaira's life began - as a concubine of Stephanos ( $\pi \alpha \lambda \lambda \alpha \kappa \eta \dot{)}$. Apollodorus claimed, however, that she "continued to carry on the same trade no less than before" ([Dem.], LIX, 41) and this income supported the family as Stephanos as a sycophant 40 "was getting nothing worth mentioning" ([Dem.], LIX, 43). Nevertheless, the accuser does not confirm this statement by any evidence, most probably exaggerating his dire financial situation ${ }^{41}$. The next twenty years in Neaira's life were tranquil and "respectable": cohabiting with Stephanus and raising his children.

The existence of the phenomenon of concubinage in the Athenian society stemmed directly from the attitude to marriage as a business deal and a means of obtaining legitimate offspring. Even though loving couples in the New Comedy often married, in reality love marriage was rather an exception. Numerous examples testify that cohabitation, albeit less dignified than marriage, implied close-knit unions and emotional bonds - such alliances came into being when a man did not want or could not take a woman as wife due to different reasons ${ }^{42}$. Concubines almost invariably were aliens as was our heroine; an Athenian woman could very rarely play this role (Is., III, 39) ${ }^{43}$. Children begotten from

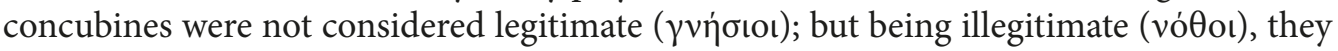
comprised part of oikos.

The mere fact of Stephanus making Neaira a woman of the house who cohabited with him for a long time and raised children together was not a justification for the accusation of Neaira of falsely obtaining citizenship, i.e. of the change of her status from a

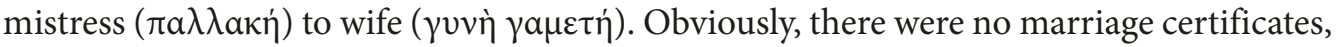
and the only difference between cohabitation and marriage pertained to legal aspects of acknowledging the status of children: it was only legal wives who gave birth to legitimate children ( $\gamma \nu \eta \dot{\sigma o \iota})$ who had access to family cult (Dem., LVI, 18) ${ }^{44}$. Apollodorus clearly differentiates between the two: "living with a woman as one's wife means - to have children by her and to introduce the sons to the members of the clan and of the deme, and to betroth the daughters to husbands as one's own" ([Dem.], LIX, 122). In order to ascertain Neaira's guilt, it was necessary to prove that her children (regardless of the fact whether they were from Stephanus of from another man) were falsely introduced to the gennetai, i.e. they were introduced to gennetai and phratry ${ }^{45}$, and at 18 - enrolled in the list of a deme; whereas for her daughter a marriage with an Athenian citizen was arranged (through formal betrothal - $\dot{\varepsilon} \gamma \gamma$ ú ). The accuser appeals to the audience: "I too have come before you to prove that Stephanus is living with an alien woman contrary to the

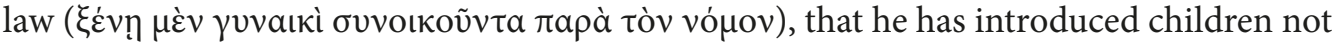

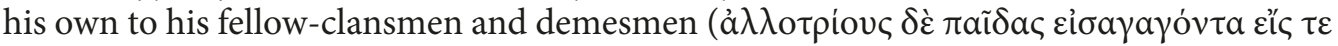

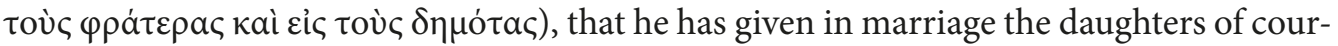

40 Apollodorus refering to Stephanus uses the term denoting a professional complainant in the sense: a person who sells his service, initiates paid lawsuits. On sycophants, see: Kudryavtseva T. V. Sikofanti i Afinskaia demokratiia // Vestnik drevnei istorii. 2007. № 2. P. 174-184.

${ }^{41}$ Carey C. Commentary // Greek Orators. Vol. VI. Apollodoros Against Neaira [Demosthenes] 59. P. 106.

42 Kapparis K. A. Apollodoros "Against Neaira”. P. 9 (with examples), 13.

43 Just is convinced that there were Athenian women among concubines (Women in Athenian Law and Life. P. 52-54); Kapparis denies it (Apollodoros "Against Neaira". P.9-10).

${ }^{44}$ For more details about what marriage was like in Athens and how it differed from concubinage, see: Just R. Women in Athenian Law and Life. P. 40-75.

${ }^{45}$ During an introduction to phratry, a father had to swear an oath that his sons were begotten from

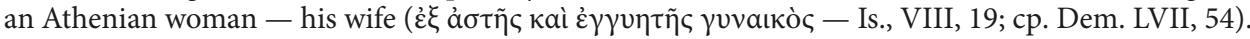




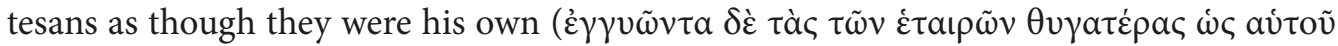

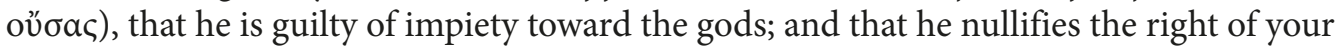
people to bestow its own favors, if it chooses to admit anyone to citizenship" ([Dem.], LIX, $13)^{46}$. Therefore, it followed that a crafty alien woman managed to sneak into the holy of holiest - the community of polis, an exclusive political and religious group to which only citizens were allowed to have access.

The strategy of defense is also obvious: Stephanos not denying that Neaira is an alien $(\xi \dot{\varepsilon} v \eta)^{47}$, will prove that he lives with her not as with a wife, but with as a concubine. Anticipating it, Apollodorus attempts to instill prejudice in judges: "I hear that he is going to set up some such defense as this-that he is keeping her, not as a wife, but as a mistress, and that the children are not hers, but were born to him by another woman, an Athenian and a relative of his, whom he will assert that he married at a earlier date" ([Dem.], LIX,

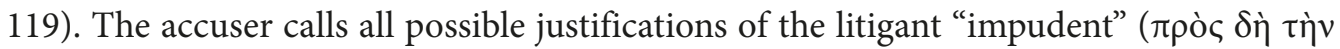

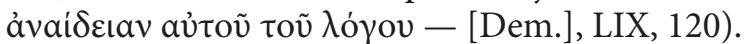

Thus, the question about the children of Neaira and/or Stephanos is of paramount importance for the trial. As it has already been said, Apollodorus stated that Neaira brought along with her from Megara three children ([Dem.], LIX, 38). It should be pointed out that the orator describing Neaira's career did not mention that she had ever been pregnant from clients or had given birth to children, who she was allowed to keep and raise. Her pregnancy must have been an obstacle for her purchase by Timanoridas and Eucrates. Undoubtedly, Nikarete's girls tried to avoid such situations: according to sources, a range of contraceptive methods and artificial termination of pregnancy by herbal concoctions and other means were in practice in antiquity ${ }^{48}$. It was unlikely that Neaira had several children from her lovers during approximately a year when she lived with them; she cohabitated with Phrynion for no longer than two years - and there was no sign of the offspring in their turbulent life; children were not mentioned among the belongings she took with her running away to Megara (Apollodorus lists maids, homeware etc.). In theory she might have given birth to three children, on condition that there were twins, during her staying in Megara, but the likelihood of it was low both in terms of everyday routine and pragmatic reasons: Neaira had to take advantage of every opportunity of making a living under the circumstances of declining demand (as it has been explained already), and two pregnancies in a row and labours could hardly contribute to it.

When Apollodorus first tells about Neaira's children, he mentions only two boys Proxenus and Ariston. In the actual fact, there is one more - Antidorides ([Dem.], LIX, $121,124)$. He bears the same name as Stephanos' father, in accordance with the tradition of naming the eldest legitimate son after the grandfather. It is almost certain that Antidorides is Stephanos' son by an Athenian wife, and to connect him to Neaira is problematic, and

46 Compare: "the woman's sons, by having been introduced to the clansmen by Stephanus, and her daughter, by having been given in marriage to an Athenian husband, prove beyond question that he keeps her as his wife" ([Dem.], LIX, 118).

47 Apollodorus places an emphasis throughout the whole speech on Neaira's alien origin $(\$ 18-117)$.

48 Plat. Theat. 149d; Aristot. Pol., VII, 1335b23-26 - about artificial termination of pregnancy. Greek medical writers knew many prescriptions for contraceptives and abortifacients, they recommended special techniques to avoid conception and if it didn't work - in order to induce a miscarriage in the early stages of pregnancy, they advised exercise, spa treatments, special decoctions and a diet of pungent food (e. g. Soran. Gynaec., I, 60-65). Details and references: Riddle J.M. Contraception and Abortion from the Ancient World to the Renaissance. Cambridge, 1992. P. 18-19, 25-56. 
the accuser prefers to draw a veil over this subject, mentioning him only at the end of the speech: to have "forgotten" about him completely would be strange as there were people in Stephanus' environment who knew full well that he has three sons. Apollodorus does not pay attention to sons: their names are mentioned only in three sections $(31,121,124)$. When the orator refers to the sons for the second time, he tells that Proxenus died and that Ariston is a short-distance runner. The plaintiff does not provide any evidence of their false legitimation as Athenian citizens or of relatives' protests against the hetaera's sons being introduced to the phratry ${ }^{49}$ - instead, he concentrates on the daughter who can easily be presented as copying her licentious mother's behavior. It is Phano who he makes the headliner of the second part of the show, or to be precise - the story of her two marriages.

She was first given in marriage to Phrastor ${ }^{50}$, from Athens, together with the dowry of thirty minae (i.e. 3000 drachmae) $)^{51}$ : taking into account the tradition of marriages, it is possible to suggest that she was from 14 to 19 , while her husband characterized as "a laboring man and one who had acquired his means by frugal living" ([Dem.], LIX, 50) was over 30 or even $40^{52}$. The marriage was unsuccessful due to the differences in habits and

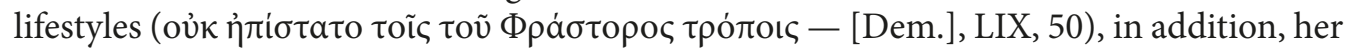
husband was of rather bad temper: Apollodorus gives away that Phrastor quarreled with his relatives and hated them ([Dem.], LIX, 55). Having lived with Phano for about a year, her husband put her away when she was pregnant and did not return her dowry ([Dem.], LIX, 51): according to the orator, Phrastor learnt that Stephanos had given him Neaira's daughter as his own ([Dem.], LIX, 54 $)^{53}$. However, it is unlikely to have been the actual reason as Phrastor had been well acquainted with the family of his prospective father-inlaw and had no suspicions of Phano's legal status. As Stephanos brought a lawsuit against

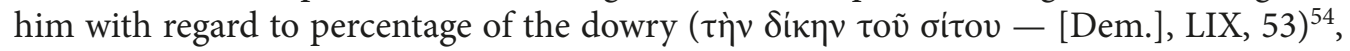
Phrastor, on his part, brought a countersuit about having been given an alien's daughter in marriage. According to Apollodorus, both sides agreed to withdraw their indictments ([Dem.], LIX, 54), i. e. ex-husband kept his marriage portion blackmailing Stephanos that his reputation would be tarnished in the case of a legal process. Phrastor had to pay a fine of 1000 drachmae as a person who appealed to an archon with a written complaint ( $ү \rho \alpha \varphi \eta \dot{\prime})$ and then refused to have court proceedings ${ }^{55}$. Stephanus' private persecution ( $\delta$ ín) was exempt from such sanctions.

49 Many scholars point out this weakness in Apollodorus' accusations. See, for example: Patteson A. J. Commentary on [Demosthenes] LIX. P. 14-15; Carey C. Commentary. P. 146; Patterson C. The Case against Neaira. P. 208; Kapparis K. A. Apollodoros "Against Neaira". P. 34; Hamel D. Trying Neaira. P. 60-61; Miner J. Courtesan, Concubine, Whore: Apollodorus' Deliberate Use of Terms for Prostitutes // American Journal of Philology. Vol. 124. 2003. P. 25-26.

50 Kirchner J. Prosopographia Attica. Bd. II. Berlin, 1903. S. 395 (14990). - All evidence about Phrastor and his family comes from this speech.

${ }^{51}$ Most likely, it was an average sum for a dowry: Patteson A. J. Commentary on [Demosthenes] LIX. P. 83; Kapparis K. A. Apollodoros "Against Neaira". P. 269, references to scholarship - Ibid.

52 Carey C. Commentary. P. 112 (circa 360); Kapparis K. A. Apollodoros “Against Neaira”. P. 284 (c. 355); Hamel D. Trying Neaira. P. 79, 173 (between 358 and 353 BC).

53 Although the orator attempts at creating an image for dikastes of Phano, the expelled spouse, as of licentious woman accustomed to riotous behaviour in the same manner as her presumptive mother, he never mentions that Phano was unfaithful or that she was not a virgin at the time of the marriage ceremony.

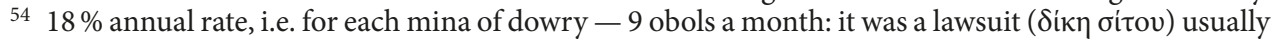

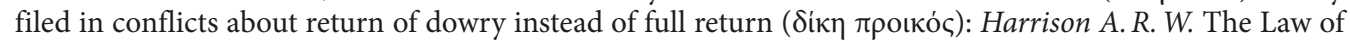
Athens: in 2 vols. Vol. I. Oxford, 1968. P. 60, 92, 93.

55 Patteson A. J. Commentary on [Demosthenes] LIX. P. 88-89. 
Soon Phrastor fell ill, and Phano, having given birth to a son by the time, began to visit her former husband with Neaira to look after him ([Dem.], LIX, 56). In the end, Phrastor acknowledged his son and introduced him to the phratry and his clansmen ([Dem.], LIX, 56-59), thus confirming that his ex-wife was an Athenian citizen. Someone of his gennetai, who had quarreled with Phano's husband, doubted the status of their son: Phrastor might have prompted them into action by his incautious accusations of the expelled spouse. They appealed to the arbitrator demanding that Phrastor should swear an oath that "he verily believed the boy to be his own son, born of an Athenian woman

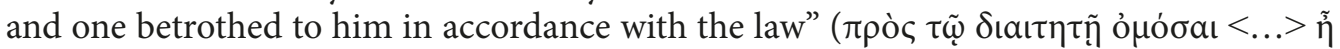

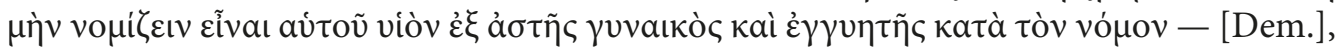
LIX, 60). Apollodorus claims that Phrastor did not take the oath ${ }^{56}$, and married another woman in a while ${ }^{57}$ ([Dem.], LIX, 58,62), however, the orator is evasive about the outcome of the lawsuit and does not mention whether the status of Phrastor's son was proven in court to be legitimate, i. e. the one with both parents being Athenian citizens. Judging by his reticence about this crucial argument for the accusation - it was not proved ${ }^{58}$.

Sometime later Epaenetus from Andros came to stay with Stephanos. Apollodorus believes that he used to be Neaira's lover who had spent a considerable sum of money on her in the past ([Dem.], LIX, 64): it is possible that it was so, or it might have been a speculation on the part of the accuser. Having caught him with Phano in adultery ( $\lambda \alpha \mu \beta a \dot{v e \varepsilon}$ Hoıxòv), Stephanos demanded thirty minae from him; the orator states that it was part of

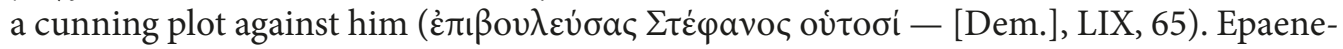
tus at first agreed but afterwards "preferred before the Thesmothetae an indictment for

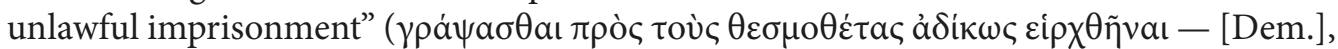
LIX, 66). He said that Stephanus' house was a brothel, and according to the law, he could not be deemed an adulterer in a place with women "who sit professionally in a brothel or who openly offer themselves for hire" ([Dem.], LIX, 67). Stephanus decided to take it to the arbitrator: it was evident that public proceedings would reduce Phano's chances of a new respectable marriage, and might mean public humiliation to the whole oikos of Stepahanus ${ }^{59}$. Arbitrators "brought about a reconciliation between them, and induced Epaenetus to contribute one thousand drachmae toward the marriage portion of Neaera's

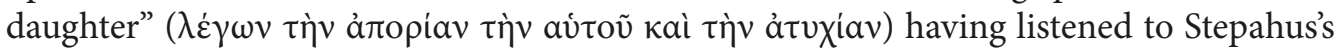
story about a pathetic state of Phano ([Dem.], LIX, 69-70).

Apollodorus tries to present Phano as a woman of easy virtue, similarly to her presumptive mother, nevertheless, he has never called the former hetaera or ró $\rho v \eta$. It was only this short-term affair with Epaenetus that he could use against her. It is possible to imagine how a young woman, having been abused by her husband and expelled from

${ }^{56}$ It is possible that the text of the oath was compiled in a cunning way which implied unfavorable interpretation for Phrastor (Kapparis K. A. Apollodoros "Against Neaira". P. 35, 290-291). Kapparis rightly points out that Phrastor must have sworn an oath about legitimacy of his son, i.e. that both parents - Athenian citizens, when he introduced a boy to the phratry (Ibid. P.282).

57 It is noteworthy that Phrastor's new spouse is not named, the orator refers to her as to "the sister of Diphilus" ([Dem.], LIX, 58) - in accordance to Athenian practice not to give names of decent women.

${ }_{58}$ The same opinion: Patteson A.J. Commentary on [Demosthenes] LIX. P.94-95; Kapparis K. A. Apollodoros "Against Neaira". P. 36, 282-284, 286; Hamel D. Trying Neaira. P.91-93. Carey supposes that the arbitrator's decision in favour of the gennetai was caused by Phrastor's refusal to take an oath (Commentary. P. 117).

59 Kapparis K. A. Apollodoros “Against Neaira”. P. 310; Hamel D. Trying Neaira. P. 100-101. 
home, being in a particular emotional state fell prey to an experienced and crafty man. If Apollodorus wanted to show that such behavior was not typical of an honest woman, he was not sincere. Athenian women took secret lover, and their husbands would catch them "red-handed", as was the case in a famous speech by Lysias "On the Murder of Eratosthenes" (Lys., I). An exemplary wife of Ischomachus from the treatise "The Oeconomicus" by Xenophon (Xen. Oikon., 7-11), according to Andocides, became the lover of her son-inlaw Callias and bore a son to him (And. Myst., 124-127) ${ }^{60}$.

In some time Stephanos and Neaira married Phano to Theogenes of Athenes ${ }^{61}$. Apollodorus characterizes him a "man of good birth, but poor and without experience in affairs" ([Dem.], LIX, 72). Stephanos wormed into his confidence and assisted him financially upon entering into office of archon basileus ([Dem.], LIX, 72) ${ }^{62}$. In gratitude, Theogenes made Stephanus his paredros ( $\pi \dot{\alpha} \rho \varepsilon \delta \rho o \varsigma ~ \gamma \varepsilon v o ́ \mu \varepsilon v o \varsigma-[D e m]$, LIX, 72) ${ }^{63}$. As a basilinna ( $\beta a \sigma i \lambda \iota v v \alpha)$, the wife of archon basileus, Phano conducted rituals and "offered on the city's behalf the sacrifices", for example, during Anthesteria ('Av $\theta \varepsilon \sigma \tau \eta \dot{\rho} \rho\llcorner$ ) "was given as bride to Dionysus" in a ritual of the sacred marriage ([Dem.], LIX, 73). Apollodorus quotes an oath of basilinna (ö $\rho \kappa о \varsigma ~ \gamma \varepsilon \rho a i \rho \omega v)$ which reads "I live a holy life and am pure

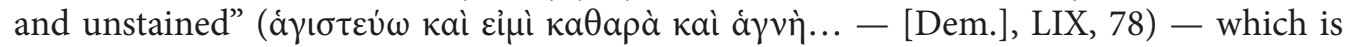
intended to contrast with impiety, corruption and lewdness of Stephanos and Neaira.

Soon Theogenes was summoned to Areopagus to give explanations about his problems with Phano, which were known to the Council. Perhaps, some members knew about Phano's first marriage or even about the argument between Prastor and his clansmen about the legitimacy of his son by Phano ${ }^{64}$. Apollodorus presents it differently: as if he had learnt from areopagites about the origin of his spouse and promised to expel her from home ([Dem.], LIX, 81). The orator alludes to the testimony of Theogenes: "Theogenes of Erchia deposes that when he was king he married Phano, believing her to be the daughter of

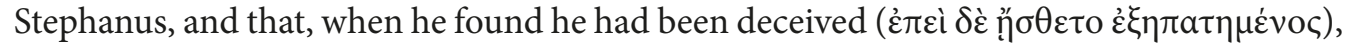
he cast the woman away..." ([Dem.], LIX, 84). It should be noted that Theogenes does not specify what the nature of the deceit had been, and Phano is not directly called Neaira's daughter, neither is given the reason for the divorce. Moreover, judging by Apollodorus' words, Areopagus did not deem this problem serious or threatening the well-being of the community. Illegitimate daughter, an alien, who becomes the spouse of archon and performs the duties of basillina, i. e. violating sacred rituals - is a serious breach guaran-

60 Harvey F. D. The Wicked Wife of Ischomachos // Echos du monde classique. Classical Views. 1984. Vol. 28. P. 68-70. - The orator reveals her name - Chrysilla - on account of her objectionable conduct as it was not customary to refer to names of honest Athenian women, as was mentioned above.

61 Kirchner J. Prosopographia Attica. Bd. I. S. 437 (6707). - The marriage to Phano might have taken place both before Theogenes's taking the position of archon (Hamel D. Trying Neaira. P. 176-177) and after (Carey C. Commentary. P. 122; Kapparis K. A. Apollodoros “Against Neaira". P. 317-318; but before his dokimasia). Kirchner dates his archontia by the middle of IV c. (Ibid.); Develin - by the beginning of the 60s (Develin R. Athenian Officials 684-321 B.C. Cambridge, 2003. P.290), but it is impossible given the chronology presented in the speech.

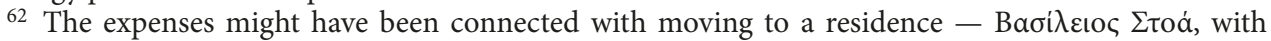
purchasing of all the necessary gowns and accessories for the rituals: Carey C. Commentary. P. 122; Kapparis K. A. Apollodoros “Against Neaira”. P. 321.

63 Three main archons (Eponymous archon, the Polemarch and the Archon basileus) selected each two assistants, paredros, who, similarly to archons, went through dokimasia and submitted reports (Aristot. Ath. pol., 56, 1; Pollux, VIII, 92).

64 Kapparis K. A. Apollodoros “Against Neaira”. P. 346-347; Hamel D. Trying Neaira. P. 108-110. 
teeing the charge of impiety ${ }^{65}$, with Stephanos and Neaira becoming the primary accused. However, Areopagus does not consider this case appropriate for court hearing in Heliaia and only reproaches simple-minded husband punishing him within their power, albeit "in secret and with due regard for appearances" ([Dem.], LIX, 80). It is probable that the real reason lay in the fact that the wife of archon basileus was supposed to be a virgin, who Phano was not ${ }^{66}$.

Undoubtedly, Apollodorus must have distorted and exaggerated a large number of details in line with Athenian court practice and rhetoric. He conceals some facts, mispresents or omits others, plays on xenophobic moods, makes use of gender prejudices, instead of providing evidence and serious arguments - appeals to feelings and attempts at dishonoring Stephanos, Neaira and her presumptive daughter Phano. He masterfully inserts gossips and modestly - obscenity and details of courtesans' sexual life, which should arouse interest of judges. Taking inro consideration expectations and stereotypes of the male audience, he portrays Neaira as a typical hetaera - corrupt, licentious, prodigal, presumptuous, uncontrollable ${ }^{67}$.

We can't hear justifications and arguments on the part of Stephanos. The plaintiff anticipates them, claiming that the former will state that Phano and boys - his children by some unknown but legitimate Athenian wife, who must have died or who he must have divorced prior to taking Neaira to his home ([Dem.], LIX, 119). It can be supposed that the defense will present their witnesses, for example, relatives of Stephanos' first wife, who will testify that he was married to a citizen (ảot门́) and had four children by her; or gennetai and demesmen who can confirm that no disputes concerning the legal status of Stephanos' sons have ever occured ${ }^{68}$.

We have traced how Neaira throughout her life managed to fulfill the role of a hetaera and concubine. Was Apollodorus able to impose upon a courtesan a third role of all possible female roles in Athens - that of a legitimate wife? If the accuser had managed to convince the judges that Neaira took this role, it would have been disastrous for her since it meant slavery and the collapse of the entire life for her, Stephanos and Phano.

The outcome of the trial is not known, neither is the fate of protagonists - Apollodorus, Stephanos and Neaira. Researches have pointed out inadequate basis for charges brought by the plaintiff, the lack of evidence for a number of statements ${ }^{69}$. Some scholars believed that Stephanos won the case ${ }^{70}$, saving his partner form the imposed role of a

${ }^{65}$ It would have caused a scandal - anyone could charge Stephanus with impiety or even use eisange-

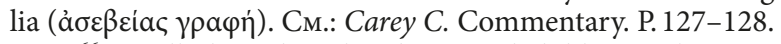

${ }^{66}$ Apollodorus has already reminded dikastes about an ancient law stemming from Theseus, according to which basillina should be of Athenian birth, a virgin who had never known another man before her

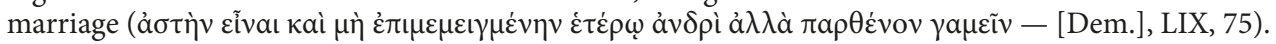

${ }^{67}$ For details see: Glazebrook A. The Making of a Prostitute: Apollodoros's portrait of Neaira // Arethusa. Vol.38. 2005. P. 161-187. - However, we categorically reject the authors' assumption that Apollodorus constructed the image of Neaira as hetaera who she might not have been in reality.

${ }^{68}$ Kapparis K. A. Apollodoros "Against Neaira". P. 40-41; Hamel D. Trying Neaira. P. 61.

69 Blass F. Die attische Beredsamkeit. Bd. III. 1. S.539-541; Patteson A. J. Commentary on [Demosthenes] LIX. P. 19; Trevett J. Apollodoros the Son of Pasion. P.99-102; Patterson C. The Case against Neaira... P. 208; Kapparis K. A. Apollodoros "Against Neaira". P. 34-41; Hamel D. Trying Neaira. P. 52-54, 60-61, $159-160$.

70 Schäfer A.D. Demosthenes und seine Zeit. Bd.III. S.183; Blass F. Die attische Beredsamkeit. Bd. III. 1. S. 539; Macurdy G. H. Apollodorus and the Speech against Neaera. P. 270; Patteson A. J. Commentary on [Demosthenes] LIX. P. 11. 
wife and corresponding bleak destiny. It is arguable that the court proceeding, even if the result was favourable for Neaira, could not but impacted Stephanos' political ambitions and prospects ${ }^{71}$.

At the same time, it was customary for dikastes to reach the verdict not exercising common sense and logic, not attempting to establish the truth and punish wrong-doers but following their emotions, sympathy and antipathy, taking account of reasons outside the judicial sphere ${ }^{72}$. It was here that Apollodorus, who was adept at manipulating perceptions of basics of polis, family identity and religious values, had a chance - Neaira might have been defeated. Dikastes were likely to have been impressed by the how Stephanos, Neaira and Phano allegedly mocked Athenian law about citizenship and sacred religious rituals - it was a hint at asebeia. There were a large number of people of modest income among judges ${ }^{73}$, and they must have reacted with indignation listening about young Athenian girls from poor families who would not be able to marry on account of the lack of resources resorting to prostitution, whereas hetaeras laid their hands on Athenian husbands, legitimized their children and shared "in all the rites and ceremonies and honors in the state" ([Dem.], LIX, 113). Let us leave a chance to our heroine: the defense will most probably try to appeal to judges' compassion and pity, and this argument might be plausible $^{74}$ : Neaira was about sixty, and it was cruel to sentence her to sale into slavery after what she had gone through, about which both modern audience and ancient heliasts learnt from Apollodorus' elaborate speech.

\section{References}

Grace (Kazakevich) E. On the concubinate in classical Athens. Vestnik drevnei istorii, 1968, no. 1, pp. $28-52$. (In Russian)

Blass F. Die attische Beredsamkeit. Bd. III. 1. Abschnitt: Demosthenes, Leipzig, Teubner, 1893, 644 S.

Carey C. Commentary. Greek Orators. Vol. VI. Apollodoros Against Neaira [Demosthenes] 59. Warminster, Aris and Phillips, 1992, pp. 84-151.

Carey C. Introduction. Greek Orators. Vol. VI. Apollodoros Against Neaira [Demosthenes] 59. Warminster, Aris and Philips, 1992, pp.1-27.

Davidson J. Courtesans and Fishcakes: The Consuming Passions of Classical Athens. London, Fontana Press, 1997, $412 \mathrm{p}$.

Davies J. K. Athenian Propertied Families (600-300 B. C.). Oxford, Oxford UP, 1971, 686 p.

Develin R. Athenian Officials 684-321 B. C. Cambridge, Cambridge University Press, 2003, 556 p.

Dovatur A. I. Slavery in Attica 6-5 c. BC. Leningrad, Nauka Publ., 1980, 136 p. (In Russian)

Glazebrook A. The Making of a Prostitute: Apollodoros's portrait of Neaira. Arethusa, 2005, vol. 38, pp. 161187.

Hamel D. Trying Neaira: the True Story of a Courtesan's Scandalous Life in Ancient Greece. New Haven, London, Yale University Press, 2003, 200 p.

Harrison A. R. W. The Law of Athens. Vol. I. Oxford, Clarendon Press, 1968, 346 p.

Harvey F. D. The Wicked Wife of Ischomachos. Echos du monde classique. Classical views, 1984, vol.28, pp. 68-70.

Just R. Women in Athenian Law and Life. London, New York, Routledge, 317 p.

Kapparis K. A. Apollodoros “Against Neaira”: [D. 59]. Berlin, New York, De Gruyter, 1999. 458 p.

${ }^{71}$ Macurdy believes that it was Apollodorus' goal (Apollodorus and the Speech against Neaera. P. 271).

${ }^{72}$ For details, see: Kudryavtseva T. V. Narodnyi sud... S. 249-258.

73 Ibid. P. 166-181.

${ }^{74}$ For cases when judicial reasons and justice were overshadowed by feelings of pity: Kudryavtseva T. V. Narodnyi sud... S.251-252. 
Keuls E. C. The Reign of the Phallus: Sexual Politics in Ancient Athens. Berkeley, California University Press, 1993, $477 \mathrm{p}$.

Kirchner J. Prosopographia Attica. Berlin, Typis et impensis Georgii Reimeri, 1901-1903. Bd. I, 603 S.; Bd. II, $660 \mathrm{~S}$.

Kudryavtseva T. V. The Sycophants and Athenian Democracy. Vestnik drevnei istorii, 2007, no. 2, pp. 174184. (In Russian)

Kudryavtseva T.V. A woman and a polis: Athenian townswoman in people's court. Gorod v Antichnosti i Srednevekov'e: obshcheevropeiskii kontekst. Doklady mezhdunarodnoi conferentsii. Ch. 2. Iaroslavl', 2010, [s.1.], pp. 14-17. (In Russian)

Kudryavtseva T. V. Magic and trials veneni crimen in the Athenian and Roman legal proceedings. Mnemon. Issledovaniia i publikatsii po istorii antichnogo mira, 2012, iss. 11, pp. 273-290. (In Russian)

Kudryavtseva T. V. The Popular Court in Democratic Athens. St. Petersburg, Aleteia Publ., 2008, 463 p. (In Russian)

Macurdy G. H. Apollodorus and the Speech against Neaera (Pseudo-Dem. LIX). American Journal of Philology, 1942, vol. 63. P.257-271.

Miner J. Courtesan, Concubine, Whore: Apollodorus' Deliberate Use of Terms for Prostitutes. American Journal of Philology, 2003, vol. 124, pp.19-37.

Patterson C. The Case against Neaira and the Public Ideology of the Athenian Family. Athenian Identity and Civic Ideology. Baltimore, London, Cambridge University Press, 1994, pp. 199-216.

Patteson A. J. Commentary on [Demosthenes] LIX: Against Neaera. Diss. in Classical Studies. Pennsylvania, University of Pennsylvania, 1978, 155 p.

Riddle J.M. Contraception and Abortion from the Ancient World to the Renaissance. Cambridge, London, Harvard, Harvard University Press, 1992, 256 p.

Sandys J.E. Introduction to Or. XLV, XLVI. Select Private Orations of Demosthenes. Pt. 2. Cambridge, 1886, pp.XXXVI-L.

Schäfer A. D. Demosthenes und seine Zeit. Bd. III. Leipzig, Teubner, 1858, 314 S.

Trevett J. Apollodoros the Son of Pasion. Oxford, Clarendon Press, 1992, 209 p.

Статья поступила в редакцию 3 июня 2020 г. Рекомендована в печать 10 декабря 2020 г.

Received: June 3, 2020

Accepted: December 10, 2020 